\title{
Study on Face Value and Amortized Cost Accounting of Bond Investment
}

\author{
Bayi Guan \\ Yantai Nanshan University \\ Yantai, Shandong, China 265713
}

\author{
Zhanli Shang \\ Yantai Nanshan University \\ Yantai, Shandong, China 265713
}

\author{
Hongwei Zhao \\ Nanshan Finance Company Ltd. \\ Yantai, Shandong, China 265706
}

\begin{abstract}
In the context of market-oriented reform of financial interest rate, the nominal interest rate and real interest rate of bond differentiates constantly, playing a certain guiding role in bond investment behavior. To calculate and measure bond investment correctly is the key for the accounting of bond investment's face value and amortized cost. Starting from the different purposes of holding bonds, this paper has explored the specific influence on bond investment accounting by the nature and goal orientation of financial assets, through the accounting and research of bonds as trading financial assets, held-tomaturity investments and the financial assets available for sale.
\end{abstract}

Keywords-bond investment; face value; amortized cost; accounting; return on investment

\section{INTRODUCTION}

The market-oriented reform of financial interest rate has draw the investors' increasing attention on bond yield, as the bond yield and risk factors influence the channel of bond investment. The accounting of bond's face value and the amortized cost is a matter of the difference of the interest receivable and investment income when the bonds' nominal interest rate and real interest rate are calculated as held-tomaturity investments and financial assets available for sale, and the balance matter resulted by different measurement bases of nominal interest rate and real interest rates.

\section{CAuses of THE Bonds' Face VAlue AND Amortized COST}

With respect to bond investment, the accounting account and handling procedure to be adopted will be different according to different purposes. In short, behavior is decided by the goal. Different goals of bond investment determine different account settings and financial treatment. It can be divided into trading financial asset, held-to-maturity investment, and financial asset available for according to different purposes at the time the investors obtain it.

When making bond investment as trading financial asset, its acquisition cost consists of the fair value of the bond and the due interest receivable but that hasn't been paid, and the transaction cost as incurred at the time of acquiring, will be treated as investment income which does not make up investment cost. During the period of holding, the due interest receivable will be calculated only in the situation of paying the interest by installment and the principal in a lump sum according to the transaction purpose of trading financial asset, and confirm the interest receivable and investment income based on face value and nominal interest rate, the interest receivable and investment income is consistent. There will be no accounting problems of amortized cost and real interest rates without real interest rates. The accounting of interest receivable of bond as trading financial assets investment has nothing to do with the book balance of trading financial assets, which will not affect the accounting of interest receivable.

The accounting of bond investment as held-to-maturity investment refers to at the time of acquiring, the expiration date and recovery amount can be determined, and the make clear that it has the ability to hold to maturity. It reveals a kind of financial capacity, holding purposing and investment time. As held-to-maturity investment, the accounting of bond refers to the amortized cost of the held-to-maturity investment, which should be measured as per fair value at the time of acquiring, and transaction costs at the time of acquiring shall be recorded as the initial cost, which forms part of the amortised cost of held-to-maturity investment, and changes in every period. At the time of acquiring, the part of the due interest but hasn't been collected shall be treated as the interest receivable, which does not constitute the amortized cost of held-to-maturity investment. The amortized cost of held-to-maturity investment account includes cost, interest adjustment and accrued interest. The amount of interest receivable or the accrued interest of the held-to-maturity investment in each period calculated by multiplying the face value of the held-to-maturity investment bond by the nominal interest rate, and the amount shall not be treated as investment income amount. The investment income of held-to-maturity investment is calculated by multiplying the amortized cost by the actual interest rate of the bond, which will exist as the opposite account's interest receivable. Generally, the two is not equal, and the difference between the two will be treated as the interest adjustment of held-tomaturity investment, and keep balance between borrowing and 
loan, which will influence the amortized cost accounting and accounting processing of the held-to-maturity investment in the nest period. The amortized cost of held-to-maturity investment will affect the accounting and confirmation of investment income.

The accounting of bond as financial assets available for sale is specified as available for sale at the time of initial confirmation, having a double selection, without the clear intent of short-term trading as it will be sold when appropriate and held if it is not suitable, with the meaning of "stop when improved" in terms of investment strategy; or during the period of held-to-maturity investment, the bond cannot be held to maturity due to the enterprise's financial problems, part of it will be sold, and the rest of the held-to-maturity investment will be calculated by converting to financial assets available for sale. Its acquisition cost is calculated by deducting the due interest receivable but hasn't been collected from the fair value of financial assets available for sale and adding the transaction cost incurred at the time of transaction. The amortized cost of financial assets available for sale consists of costs, interest adjustment, changes in fair value, and accrued interest. The interest receivable of financial assets available for sale is calculated by multiplying face value of the bond (i.e., cost) by the nominal interest rate, which will be treated as the debtor's interest receivable, and not treated as the lender's investment income. The lender's investment income as obtained from bond investment of financial assets available for sale is calculated by multiplying the amortized cost by the actual interest rate, which will be recorded as the interest adjustment together with the interest receivable difference between debtor and lender, to keep account balance between debtor and lender. The fair value calculation mode is adopted for financial assets available for sale during the period of holding; therefore the detailed changes in the formation items of its amortized cost also have the schedule of changes in fair value. The amortized cost of financial assets available for sale affects the calculation of investment income.

\section{ESSENCE OF INTEREST RECEIVABLE AND ACCRUED INTEREST}

As for bonds, they all have face value and nominal interest rate as well as actual interest rate, which is the foundation for accounting of interest receivable or accrued interest. Whether they are calculated as bonds or trading financial assets or as held-to-maturity investment and financial assets available for sale, their interest receivable or accrued interest are calculated based on face value, nominal interest rate and actual interest rate. In practice, the due interest that hasn't been collected at the time of acquiring shall be treated as interest receivable whether it is trading financial asset, held-to-maturity investment, or financial asset available for sale, which will not form the initial costs.

Two aspects shall be taken into consideration when accounting based on face value, name interest receivable and accrued interest. As for trading financial assets, because its holding purpose is to earn price difference, therefore, on the date of balance sheet, only the interest of bond with interest being paid in installment and principal being paid in a lump sum will be calculated, and calculate the interest receivable based on face value and nominal interest rate and treat it as the investment income; the interest of the bond with the principal and interest being paid in a lump sum will not be calculated, because generally, trading financial assets will not be held to maturity due to its by short-term trading nature, of which the accrued interest has been included in the fair value, and will be measured by changes in fair value, so interest calculation will not be conducted. As for the held-to-maturity investment, and financial assets available for sale, because it will be hold for a long term, not only the interest receivable of the bond investment with interest being pain in installment and the principal being paid in a lump will be calculated in the balance sheet, but also the accrued interest of held-to-maturity investment and the accrued interest of financial assets available for sale will be calculated respectively for the bond investment with principal and interest being paid in a lump sum in the balance sheet. Neither the interest receivable nor the accrued interest will be taken as the recording basis of investment income.

\section{EXAMPLES OF THE ACCOUNTING OF BOND INVESTMENTS' FACE VALUE AND AMORTIZED COST}

The account setting and accounting treatment in terms of accounting at the time of acquiring and during the period of holding will be different due to different bond investment purposes. According to different bond investment purposes, there are accounting applications of the accounting of bonds' face value and amortized cost conducted for trading financial assets, held-to-maturity investment and financial assets available listed as below.

\section{A. Accounting of Trading Financial Assets Investment}

The bond shall be calculated as trading financial assets when the bond holders hold the bond for earning price differences in short term. At the time of obtaining this investment, the trading financial assets shall be recorded as initial cost with fair value, and transaction cost will not be recorded in the initial cost but calculated as investment income. As for the bond investment calculated as trading financial assets, there is no calculation of actual interest rate due to its purpose of transaction, and the interest receivable will only be calculated as per nominal interest rate.

[Application 1] On January 1, 2014 Shanquan Company purchased the bonds issued by Haiyang Company, which was issued on July 1, 2013, with face value of 30,000,000 yuan, and annual nominal interest rate of $4 \%$. The bond interest of previous year will be paid at the beginning of next year, and the company divided it as trading financial assets, and paid the payment of 32,000,000 yuan (including 600,000 yuan of due bond interest that hasn't been collected), in addition, 320,000 of the transaction costs was paid. On January 10, 2014, Shanquan Company received 600,000 yuan of the bond interest. On January 10, 2015, Shanquan Company received $1,200,000$ yuan of the bond interest. Please deal with the accounting of interest and investment income as well as the accounting treatment at the time of acquiring and during the period of holding when taking the bond investment as trading financial assets. 
1) Conduct the following processing when Shanquan Company obtained the bonds from Haiyang Company on January 1, 2014:

Borrow: Trading financial assets - bonds of Haiyang Company - cost 26,000,000 (32,000,000-600, 000)

Interest receivable - Haiyang Company 600,000

$$
(30,000,000 * 4 \% / 2)
$$

Investment income

Loan: Other monetary fund- deposited investment fund $32,320,000$

2) On January 10, 2014, when Shanquan Company received the due interest but hadn't been collected at the time of purchasing:

Borrow: Other monetary fund- deposited investment fund 600,000

Loan: Interest receivable-Haiyang Company

600,000

3) On December 31, 2014, when it was confirmed that the bond interest income of Haiyang Company was 1,200,000 $(30,000,000 * 4 \%)$ :

Borrow: Interest receivable - Haiyang Company

$$
1,200,000
$$

Loan: Investment income

\section{$1,200,000$}

4) On January 10, 2015, when receiving the bond interest from Haiyang Company:

Borrow: Other monetary fund-deposited investment fund

$$
1,200,000
$$

Loan: Interest receivable-Haiyang Company

$$
1,200,000
$$

In conclusion, during the period of holding, the bond interest of trading financial assets for each period is calculated based on the nominal interest rate and face value, and it is the same for each period.

\section{B. Accounting of Held-to-maturity Investment}

When the bonds are calculated as held-to-maturity investment, it reflects the time limit of holding period, the stability of the financial capacity and clarity of the target. Therefore, the income difference between face value and nominal interest rate, amortized cost and actual interest rate is generated, and the interest adjustment accounting is needed.

[Application 2] On January 1, 2014 Shanquan Company purchased the bonds issued by Haiyang Company, which was issued on July 1, 2013, with face value of 30,000,000 yuan, and annual nominal interest rate of $4 \%$. The bond period of Haiyang Company is 5 years. The bond interest of previous year will be paid at the beginning of next year with the principal to be paid in a lump sum at the expiration date of the bonds. The company divided it as trading financial assets, and paid the payment of 32,000,000 yuan (including 600,000 yuan of due bond interest that hasn't been collected), in addition, 320,000 of the transaction costs was paid. On January 10, 2014, Shanquan Company received 600,000 yuan of the bond interest. On January 10, 2015, Shanquan Company received $1,200,000$ yuan of the bond interest. Please deal with the accounting of interest, amortized cost and investment income as well as the accounting treatment at the time of acquiring and during the period of holding when taking the bond investment as trading financial assets.

1) Conduct the following processing when Shanquan Company obtained the bonds of Haiyang Company on January 1, 2014:

Borrow: Held-to-maturity investment-Haiyang Company bond-cost $\quad 30,000,000$

Held-to-maturity investment-Haiyang Company bondinterest adjustment $\quad 1,720,000$

Interest receivable-Haiyang Company
600,000

Loan: Other monetary fund-deposited investment fund $32,320,000$

2) On January 10, 2014, when Shanquan Company received the due interest but hadn't been collected at the time of purchasing:

Borrow: Other monetary fund-deposited investment fund 600,000

Loan: Interest receivable-Haiyang Company
600,000

3) At the end of 2014, the amortized cost of this held-tomaturity investment was 30,000,000+1,720,000=31,720,000 (yuan), investment income was $31,720,000 * 10 \%=3,172,000$ (yuan), and the interest receivable of 2014 was $30,000,000 * 4 \%=1200000$ (yuan), the accounting treatment will be conducted as below:

Borrow: Interest receivable-Haiyang Company $1,200,000$

Held-to-maturity investment-Haiyang Company bond-interest adjustment 1,972,000

Loan: Investment income

3172000

4) On January 10, 2015, when receiving the bond interest from Haiyang Company:

Borrow: Other monetary fund-deposited investment fund $1,200,000$

Loan: Interest receivable-Haiyang Company $1,200,000$

In conclusion, the interest receivable or accrued interest of the held-to-maturity investment in each period remains unchanged, just the change of amortized cost causes the changes in investment income in each period. If held-tomaturity investment is devalued during the period of holding, then it will reduce the amortized cost, thus reduce the investment income. 


\section{Accounting of the Financial Assets Available for Sale}

According to the investment purposes of holding bonds, there was the intent of available for sale at the time of initial confirmation. Therefore, its value shall be calculated as per fair value, and then change and adjust its nominal value, which will influence profits and losses of the current period.

Still take [Application 2] as an example, suppose that Shanquan Company divided the bond investment as financial assets available for sale after acquiring with other conditions unchanged. The accounting and accounting treatment at the time of acquiring and during the period of holding of this bond investment as financial assets available for sale shall be processed as below.

1) Conduct the following processing when Shanquan Company obtained the financial assets available for sale on January 1, 2014:

Borrow: Financial assets available for sale-Haiyang Company bond - cost 30,000,000

Financial assets available for sale-Haiyang Company bond - interest adjustment 1,720,000

Interest receivable-Haiyang Company 600,000

Loan: Other monetary fund-deposited investment fund $32,320,000$

2) On January 10, 2014, when Shanquan Company received the due interest but hadn't been collected at the time of purchasing:

Borrow: Other monetary fund-deposited investment fund 600,000

Loan: Interest receivable-Haiyang Company 600,000

3) At the end of 2014, the amortized cost of the financial assets available for sale was $30,000,000+1,720,000=31,720,000 \quad$ (yuan), investment income was $31,720,000 * 10 \%=3,172,000$ (yuan), and the interest receivable of 2014 was 30,000,000*4\%=1 200000 (yuan), the accounting treatment will be conducted as below:

Borrow: Interest receivable-Haiyang Company $1,200,000$

Financial assets available for sale-Haiyang Company bond-interested adjustment 1,972,000

Loan: Investment income $3,172,000$

4) On January 10, 2015, when receiving the bond interest from Haiyang Company:

Borrow: Other monetary fund-deposited investment fund $1,200,000$

Loan:

Interest

receivable-Haiyang

Company $1,200,000$

In conclusion, the interest receivable or accrued interest of the financial assets available for sale in each period remains unchanged, and the changes in amortized cost influence the investment income in each period. The value change is temporary if the financial asset available for sale is calculated as per fair value, without affecting the amortized cost changes. If financial asset available for sale is devalued during the period of holding, then it will reduce the amortized cost, thus reduce the investment income.

\section{CONCLUSION}

There are differences in pricing methods and accounting methods due to different purposes of the holders toward the bond investment, thus different settings and accounting treatments are generated. Whether it is trading financial asset, held-to-maturity investment, or the financial asset available for sale, because its nature of bond investment is unchanged, therefore, when accounting the interest receivable or accrued interest of each period, the face value and nominal interest rate are adopted, and it remains the same in each accounting period; however, just because the holding purposes of held-to-maturity investment and financial assets available for sale are significantly differing from that of the short-term transaction of trading financial assets, therefore, there exists the investment income accounting of the amortized cost and actual interest rate, which is determined by the investment purposes of the latter two financial assets.

\section{REFERENCES}

[1] Yuan Ying. Measurement of Amortized cost under Dual Measurement Mode. Finance and Accounting Monthly [J], 2014; 13.

[2] No.22 of Accounting Standards for Business Enterprises-Financial Tools Confirmation and Measurement (Published by the Ministry of Finance on February 15, 2006, and start to be implemented among listed companies since January 1, 2007).

[3] Accounting Qualification Evaluation Center of Ministry of Finance. Junior Accounting Practices [M].Beijing: China Financial and Economic Publishing House, 2015. 